\title{
Aluminothermic Reduction of Manganese Oxide from Selected MnO-Containing Slags
}

\author{
Artur Kudyba ${ }^{1, *}$, Shahid Akhtar ${ }^{2}$, Inge Johansen ${ }^{2}$ and Jafar Safarian ${ }^{1}$ \\ 1 Department of Materials Science and Engineering, Norwegian University of Science and Technology (NTNU), \\ Alfred Getz Vei 2, 7034 Trondheim, Norway; jafar.safarian@ntnu.no \\ 2 Hydro Aluminum, Romsdalsvegen 1, 6600 Sunndalsøra, Norway; shahid.akhtar@hydro.com (S.A.); \\ inge.johansen@hydro.com (I.J.) \\ * Correspondence: artur.kudyba@ntnu.no; Tel.: +47-462-44-097
}

Citation: Kudyba, A.; Akhtar, S.; Johansen, I.; Safarian, J.

Aluminothermic Reduction of Manganese Oxide from Selected MnO-Containing Slags. Materials 2021, 14, 356. https://doi.org/ $10.3390 / \mathrm{ma} 14020356$

Received: 11 December 2020 Accepted: 11 January 2021 Published: 13 January 2021

Publisher's Note: MDPI stays neutral with regard to jurisdictional clai$\mathrm{ms}$ in published maps and institutional affiliations.

Copyright: (C) 2021 by the authors. Licensee MDPI, Basel, Switzerland. This article is an open access article distributed under the terms and conditions of the Creative Commons Attribution (CC BY) license (https:// creativecommons.org/licenses/by/ $4.0 /)$.

\begin{abstract}
The aluminothermic reduction process of manganese oxide from different slags by aluminum was investigated using pure $\mathrm{Al}$ and two types of industrial $\mathrm{Al}$ dross. Two types of $\mathrm{MnO}-$ containing slags were used: a synthetic highly pure $\mathrm{CaO}-\mathrm{MnO}$ slag and an industrial high carbon ferromanganese slag. Mixtures of $\mathrm{Al}$ and slag with more $\mathrm{Al}$ than the stoichiometry were heated and interacted in an induction furnace up to $1873 \mathrm{~K}$, yielding molten metal and slag products. The characterization of the produced metal and slag phases indicated that the complete reduction of $\mathrm{MnO}$ occurs via the aluminothermic process. Moreover, as the $\mathrm{Al}$ content in the charge was high, it also completely reduced $\mathrm{SiO}_{2}$ in the industrial ferromanganese slag. A small mass transport of $\mathrm{Ca}$ and $\mathrm{Mg}$ into the metal phase was also observed, which was shown to be affected by the slag chemistry. The obtained results indicated that the valorization of both $\mathrm{Al}$ dross and FeMn slag in a single process for the production of $\mathrm{Mn}, \mathrm{Mn}-\mathrm{Al}$, and Mn-Al-Si alloys is possible. Moreover, the energy balance for the process indicated that the energy consumption of the process to produce Mn-Al alloys via the proposed process is insignificant due to the highly exothermic reactions at high temperatures.
\end{abstract}

Keywords: aluminothermic reduction; Al dross; FeMn; slag

\section{Introduction}

Aluminum is the most abundant metallic elements in the Earth's crust, posing an excellent combination of chemical, mechanical, and physical properties which makes it suitable for many applications [1]. Aluminum is mainly produced by two different methods: (I) a primary aluminum production from bauxite ore by the Bayer process for alumina extraction followed by Hall-Heroult electrolysis for $\mathrm{Al}$ extraction from alumina, and (II) by recycling aluminum from process scrap and wasted aluminum products [2-4]. In 2019, the global production of metallic aluminum was approx. 64 million metric tons, with a daily average of 174.5 thousand tons [5]. As a result of the exposure of liquid aluminum to the oxidizing atmosphere that is present during the process of melting and alloying, a surface oxidation takes place, leading to the formation of a semisolid skin over the molten $\mathrm{Al}$ metal, which also hinders further oxidation. This floating skin over liquid $\mathrm{Al}$ is called aluminum dross and consists mainly of aluminum oxide, metallic aluminum, magnesium spinel, periclase, and quartz [6,7]. There are two types of Al dross: (I) White Dross (the primary dross), which is formed during the primary production of aluminum (mainly aluminum ingots), containing approximately $15-80 \%$ metallic aluminum, $20-85 \%$ aluminum oxide, and 5\% salts, and (II) Black Dross (the secondary dross), which is a byproduct of the secondary production of aluminum, containing 7-50\% metallic aluminum, $30-50 \%$ aluminum oxide, and $30-50 \%$ salt flux [8-12]. Each year, the world aluminum industry produces approximately four million tonnes $(\mathrm{Mt})$ of Aluminum White Dross (AWD) and more than a million tonnes of Aluminum Black Dross (ABD), and around 95\% of this material (ABD) is landfilled $[4,13]$. Aluminum dross is a potential toxic industrial 
waste inevitably generated in aluminum smelter plants. The safe disposal of Al dross as a waste is a burden to the aluminum industry because of the effects of improper disposal on the eco-system. Owing to the large annual production of Al dross and its environmental and economic impacts, aluminum dross undergoes industrial treatments to extract valuable products, including metallic aluminum. Two methods of Al dross treatment are used: (I) a pyrometallurgical route, which is a conventional method of treating Al dross, liberating metallic aluminum in the liquid state, and (II) a hydrometallurgical route, which involves the extraction of metallic aluminum from the $\mathrm{Al}$ dross by converting it into aluminum salts and compounds. The recycling of aluminum dross is crucial for environmental protection, economic reasons, and sustainable development with regard to circular ("zero waste") economy.

Manganese is ranked as the 12th most abundant element in the Earth's crust, is applied in the steel and aluminum industry, and in its elemental and alloy forms is used as an alloying element. The massive production of manganese is via the carbothermic reduction of Mn ores in submerged arc furnaces, which yields Mn ferroalloys such as high-carbon ferromanganese (HCFeMn) and silicomanganese, SiMn [14]. In 2019, about 4.4 and 7.7 Mt of HCFeMn and SiMn were produced, respectively. In addition, 1.43 and $1.62 \mathrm{Mt}$ of refined ferromanganese and manganese metal were fabricated [15]. A by-product of the HCFeMn process is a slag that contains a considerable amount of $\mathrm{MnO}$, usually in the range of 20-45\% $\mathrm{MnO}$, along with other oxides such as $\mathrm{CaO}, \mathrm{MnO}, \mathrm{MgO}, \mathrm{Al}_{2} \mathrm{O}_{3}$, and $\mathrm{SiO}_{2}$ [16]. If HCFeMn slag is not utilized in SiMn production, it is landfilled or used in other industries. It contains a significant amount of Mn element and its valorization to extract $\mathrm{Mn}$ is also important from the circular economy point of view.

A literature survey [17-24] revealed a few works on the aluminothermic reduction of $\mathrm{MnO}$ by dissolved $\mathrm{Al}$ in a continuous galvanizing bath. However, in the available literature there is a limited number of studies analyzing the results of the aluminothermic reduction of manganese oxide using real industrial materials such as Al dross or FeMn slag. Dávila et al. [17] investigated the effect of magnesium concentration in the molten aluminum produced from beverage cans on the process of the aluminothermic reduction of $\mathrm{Mn}_{2} \mathrm{O}_{3}$ particles obtained from the cathodes of discharged alkaline batteries. The authors have proven that the magnesium content of the base alloy is a very important factor in the aluminothermic reduction, since this element improves the wettability of aluminum on the $\mathrm{Mn}_{2} \mathrm{O}_{3}$ particles, which in turn supports solid/liquid reaction. Kavitha and McDermid [18] have investigated the aluminothermic reduction of $\mathrm{MnO}$ by dissolved $\mathrm{Al}$ in the continuous galvanizing process. They conclude that the $\mathrm{MnO}$ reduction reaction is a relatively simple dissolution reaction in which the composition of the $\mathrm{MnO}$ layer was not altered during the reaction. Furthermore, the thickness of the thin $\mathrm{Al}_{2} \mathrm{O}_{3}$ reaction product was relatively constant (3-4 nm) for all the reaction times investigated. Jiaxing et al. [22] studied the aluminothermic reduction of pure $\mathrm{MnO}_{2}$ by metallic Al particles through a thermite process, and studied the conversion of $\mathrm{MnO}_{2}$ to $\mathrm{Mn}_{2} \mathrm{O}_{3}$ and $\mathrm{Mn}_{3} \mathrm{O}_{4}$ using Differential Scanning Calorimetry (DSC) techniques. They have provided information about the heat generation due to the reactions at temperatures below $900{ }^{\circ} \mathrm{C}$, but they have not produced metallic manganese in their experiments. Sarangi et al. [23] studied the reaction between $\mathrm{MnO}_{2}$ and $\mathrm{Al}$ powders using the Differential Thermal Analysis (DTA) technique and determined the heat generation due to aluminothermic reduction reactions, varying the $\mathrm{MnO}_{2} / \mathrm{Al}$ ratio. Based on the rate of heat generation in DTA experiments, they calculated the rate of the reduction reaction and further performed a kinetic study. Bhoi et al. [24] studied the aluminothermic reduction of a manganese ore particles by Al powder to produce ferromanganese, and used lime and fluorspar in their mixtures. They performed reduction reactions via roasting at moderate temperatures of $650{ }^{\circ} \mathrm{C}$ and $950{ }^{\circ} \mathrm{C}$, and produced ferromanganese samples with 70-80 wt.\% Mn and 12-16 wt.\% Fe. In all these studies, pure $\mathrm{Al}$ powders were used, and pure $\mathrm{MnO}_{2}$ or manganese ore were applied as the manganese oxide source [22-24]. The novelty of the present study is established by following features: (1) the $\mathrm{Al}$ reactant is not a pure powder, but rather industrial $\mathrm{Al}$ 
dross; (2) the source of manganese oxide is not pure manganese oxide powder, but rather industrial ferromanganese slag, which is a complex material; (3) the previous researchers applied the thermite process, in which the mixtures of powdered materials are heated to moderate temperatures, usually below $1000^{\circ} \mathrm{C}$, while in the present study we heat up the reactants to much higher temperatures to obtain all the charged mixtures in a molten state; (4) the present work is more oriented towards an evaluation of the products, and the target product is Al-Mn alloy, not Mn oxide or ferromanganese.

As is mentioned above, the present work is focused on the high-temperature aluminothermic reduction process of $\mathrm{MnO}$ from synthetic and industrial HCFeMn slags by pure $\mathrm{Al}$ and two industrial AWDs. The main chemical reaction of the process at elevated temperatures can be written as:

$$
3 \mathrm{MnO}+2 \mathrm{Al}=3 \mathrm{Mn}+\mathrm{Al}_{2} \mathrm{O}_{3} \Delta \mathrm{H}\left(1500^{\circ} \mathrm{C}\right)=-466.5 \mathrm{~kJ} / \mathrm{mol} .
$$

Obviously, the highly exothermic nature of this reaction is beneficial regarding the overall process energy consumption. Moreover, thermodynamic software (FactSage ver. 7.3.) is used to discuss the results and find the mass and energy balances.

\section{Experimental Procedure}

The materials preparation and applied methodology are described as follows.

\subsection{Material Preparation}

Two aluminum dross samples were collected from skimmed dross over the surface of molten primary $\mathrm{Al}$ and an Al-Si-Mn alloy (grade series 1000 and 4000, respectively). In order to directly extract a representative Al dross sample from the surface of the molten alloy, a special sampling tool was designed and developed. Initially, the sampling tool was introduced into a dross tub, and when the $\mathrm{Al}$ dross was skimmed from the reverberatory furnace into the tub in which the tool was positioned in, a portion of the hot dross was collected from the surface of the molten alloy by the sampling unit. The thickness of the dross layer collected for testing was in the range of 20-30 cm. The dross 1 (from the primary $\mathrm{Al}$ ) was used in its original form, and the dross 2 (from the Al-Si-Mn alloy) was subjected to a mechanical ball milling at room temperature to separate the fine oxide and the inclusion of the dross and to obtain rich metallic Al-containing particles. After the mechanical treatment, the milled dross 2 was partitioned by sieving and a particle size of $1.25-2 \mathrm{~mm}$ was further used. The microstructures and characteristics of these dross samples were studied by the Zeiss Ultra 55 Scanning Electron Microscope (SEM, Carl Zeiss Microscopy $\mathrm{GmbH}$, Jena, Germany), coupled with energy-dispersive X-ray spectroscopy (EDS) and XRay Diffraction (XRD) (Bruker D8 A25 DaVinci X-ray Diffractometer with CuK $\alpha$ radiation with LynxEye ${ }^{\mathrm{TM}}$ SuperSpeed Detector $[25,26]$ (Bruker Corporation, Billerica, MA, USA). In this study, a high-purity Al metal (99.9\%) was used for a trial.

Two types of MnO-containing slags were used in this study: a binary $\mathrm{CaO}-\mathrm{MnO}$ synthetic slag and an industrial HCFeMn slag received from the industry, which was characterized by PANalytical Zetium $4 \mathrm{~kW}$ X-ray Fluorescence (XRF, Malvern Panalytical Ltd, Malvern WR14 1XZ, UK). The synthetic slag was made by mixing pure $\mathrm{CaO}$ and $\mathrm{MnO}$ (above $99 \%$ purity level) oxides, and then melting in a top open induction furnace at $1873 \mathrm{~K}$ in a graphite crucible to obtain a $\mathrm{CaO} 25 \mathrm{wt} . \%$. Pure $\mathrm{Al}$ and the dross 1 particles $(1-10 \mathrm{~mm})$ were mixed with the synthetic slag. The dross $2(1.25-2 \mathrm{~mm})$ was mixed with the HCFeMn slag, whereas $\mathrm{CaO}$ was in addition added with masses of about $10 \%$ and $25 \%$. The addition of $\mathrm{Al}$ reductants to reduce the synthetic slag was required two times for the reduction of all $\mathrm{MnO}$ in the slag, and the utilized mass of dross 1 was approximated $69 \mathrm{~g}$, as it contains a significant amount of $\mathrm{Al}_{2} \mathrm{O}_{3}$, which was estimated to be $34 \mathrm{wt} . \%$, while for the $\mathrm{HCFeMn}$ slag the same masses amount of treated dross 2 was used. The charge mixture details are given in Table 1. The mixtures were charged into alumina crucibles, and then they were put in graphite crucibles, as is schematically shown in Figure 1a. 
Table 1. The charge mixture details.

\begin{tabular}{ccccccc}
\hline Exp. Number & Synthetic Slag $(g)$ & HCFeMn Slag $(g)$ & CaO Addition (g) & Al Metal (g) & Al Dross (g) \\
\hline 1 & 166 & - & - & 46 & - \\
2 & 166 & - & - & - & Dross $1^{* *}: 69$ \\
3 & - & 49.5 & 11 & - & Dross $2 * *: 49.5$ \\
4 & - & 50.2 & 25.15 & - & Dross $2 * *: 50.2$ \\
\hline
\end{tabular}

*-Dross 1 with a particle size: $1-10 \mathrm{~mm}$. ${ }^{* *}$-Dross 2 with a particle size: $1.25-2 \mathrm{~mm}$.

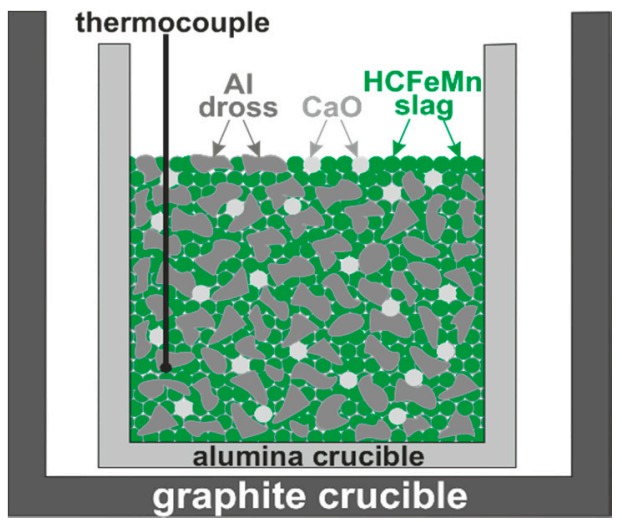

(a)

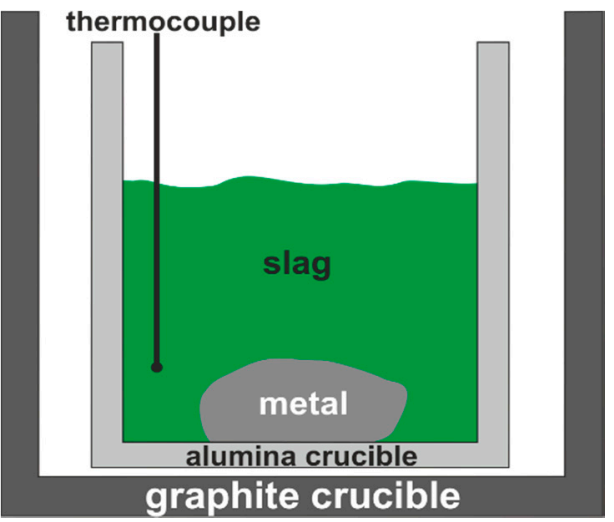

(b)

Figure 1. A scheme of (a) charged materials for exp. 3 in crucible before the reaction test, and (b) the produced slag and metal after reactions.

\subsection{Aluminothermic Reduction}

The crucibles with the charge mixtures were put in an induction furnace and a thermocouple was put into the charge mixture to measure the temperature inside the crucible. Each crucible was heated at about a $293 \mathrm{~K} / \mathrm{min}$ rate up to $1773 \mathrm{~K}$ and held for $30 \mathrm{~min}$ in a protective atmosphere (flow gas Ar 5.0 at a constant pressure of $1030 \mathrm{mbar}$ ). The temperature recordings indicated the reaction kinetics, and it was observed that, upon reaching the target temperature $(1773 \mathrm{~K})$ for a few minutes, the temperature in the crucible was rapidly increased to a maximum in the range of 1973-2073 K, indicating that an aluminothermic reaction (1) was rapidly taking place. After that, the temperature inside the crucible declined to the target temperature. Then, the furnace power was turned off and consequently the molten components solidified. The metal is much heavier than the slag and it sinks in the crucible, as schematically illustrated in Figure $1 \mathrm{~b}$.

The produced metal and slag were separated after breaking the crucibles, and metallography samples were produced from them via mounting in epoxy resin followed by grinding and metallographic polishing. The structure and chemical composition were characterized using a Zeiss Ultra 55 SEM coupled with EDS.

\section{Results and Discussion}

The obtained results for the materials and products are presented and discussed as follows.

\subsection{Reactant Materials Characteristics}

The results of the SEM and EDS microstructural analyses of the separated Al dross particles with 1.25-2 mm sizes that were later used in the aluminothermic reduction are shown in Figure 2. Figure 2a shows a few particles (mounted in resin) and all the particles show two main components: a major metallic portion and a darker non-metallic portion. A microstructural analysis of the particles with a size below $1.25 \mathrm{~mm}$ indicated a significantly higher non-metallic portion as compared to that of the larger particles. The elemental X-ray mapping of the main elements in Figure 2 shows clearly these dross parts. 
A semiquantitative $\mathrm{XRD}$ analysis of the fine particles under $1 \mathrm{~mm}$ in Figure 3 indicated that about $50 \%$ of the material is $\mathrm{Al}_{2} \mathrm{O}_{3}, \mathrm{AlN}$, and $\mathrm{SiO}_{2}$, and the rest is metallic $\mathrm{Al}$ and $\mathrm{Si}$. Hence, in the utilized $1.25-2 \mathrm{~mm}$ particles, we may have the same compounds but in a smaller total amount of about $18 \%$, as approximated by image analysis. Hence, the metallic portion of these particles is about $80 \%$. The SEM microstructural study of dross 1 indicated that almost $2 / 3$ of the material was metallic and the rest was aluminum oxide, and this was the basis for using more mass of dross 1 in experiment 2 compared to experiment 1 (Table 1).

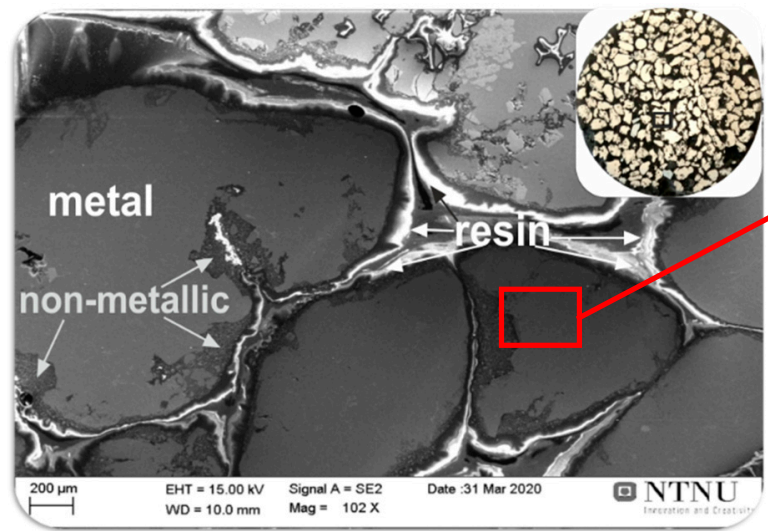

(a)

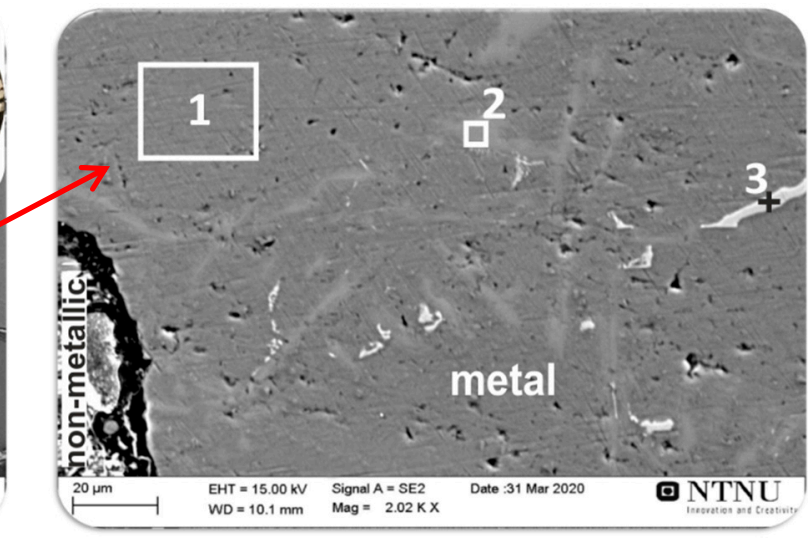

(b)

\begin{tabular}{|c|c|c|c|c|c|c|}
\hline \multirow{2}{*}{ Point } & \multicolumn{6}{|c|}{ Chemical composition (wt. \%) } \\
\cline { 2 - 7 } & Al & Si & Mn & Mg & O & C \\
\hline 1 & 91.90 & 1.71 & 0.09 & 0.83 & 0.79 & 4.68 \\
\hline 2 & 5.78 & 83.76 & 0.02 & 0.22 & 0.56 & 9.66 \\
\hline 3 & 70.89 & 9.91 & 11.57 & 0.76 & 0.00 & 6.87 \\
\hline
\end{tabular}
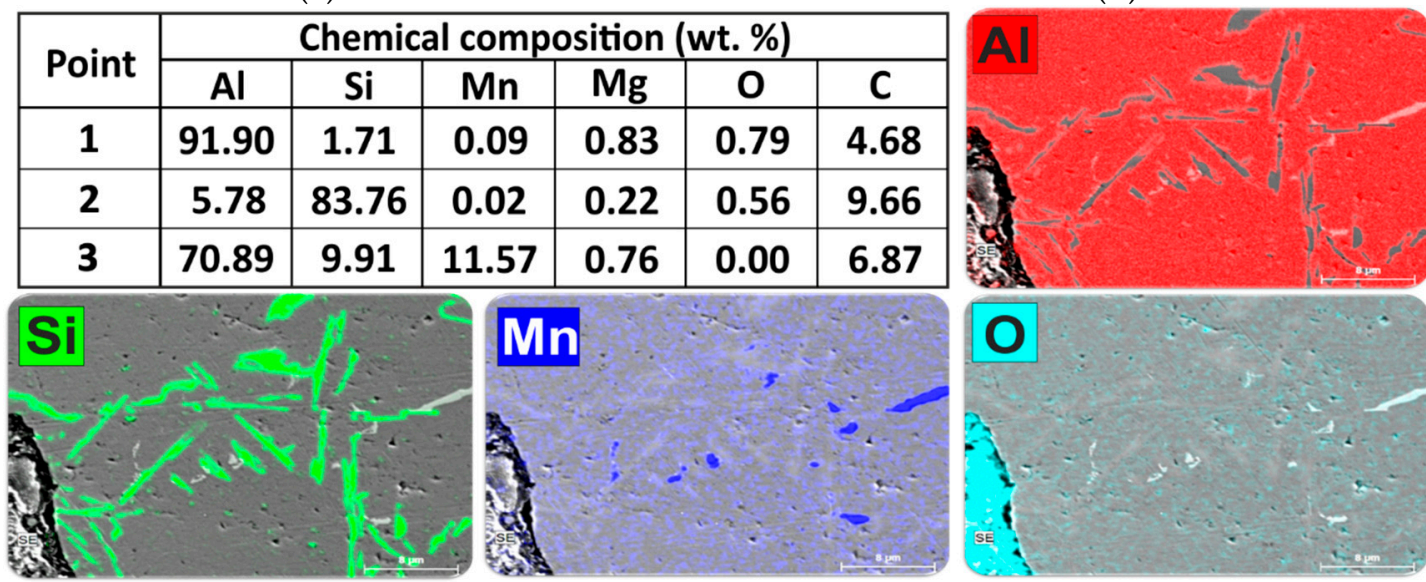

(c)

Figure 2. The SEM/EDS microstructural analysis results of particles of Al dross of size 1.25-2 mm used in the aluminothermic reduction: Scanning Electron Microscope-Backscattered Electrons images (a,b), EDS mapping (c).

It was found that the metallic portion of the $\mathrm{Al}$ dross particles has three main phases: an $\mathrm{Al}$ matrix that contains large and small Si particles (area 1 in Figure 2b), an area that contains fine and large Si particles (area 2 in Figure 2b), and an Mn-rich phase (point 3 in Figure $2 b$ ). In area 2 in Figure 2b, the Si phase was identified to contain around 84 wt.\% Si; however, as $\mathrm{Al}$ has insignificant solubility in $\mathrm{Si}$, we may conclude that the detected $\mathrm{Al}$ is from the matrix and this phase is pure Si.

The results of the XRF chemical analysis of HCFeMn slag are presented in Table 2. It was found that the dominant component is manganese oxide (46 wt.\%). The second phase identified in the material is $\mathrm{SiO}_{2}$, which constitutes about 19 wt.\%, followed by $\mathrm{CaO}$ and $\mathrm{Al}_{2} \mathrm{O}_{3}$, which are around 14 and $11 \mathrm{wt} . \%$, respectively. The slag contains minor amounts of $\mathrm{K}_{2} \mathrm{O}, \mathrm{BaO}, \mathrm{SO}_{3}, \mathrm{Na}_{2} \mathrm{O}, \mathrm{TiO}_{2}$, and $\mathrm{SrO}$. As the material is smelted at elevated temperatures, the form of the slag phases in solid state is not important and XRD analysis was not necessary in this study. 


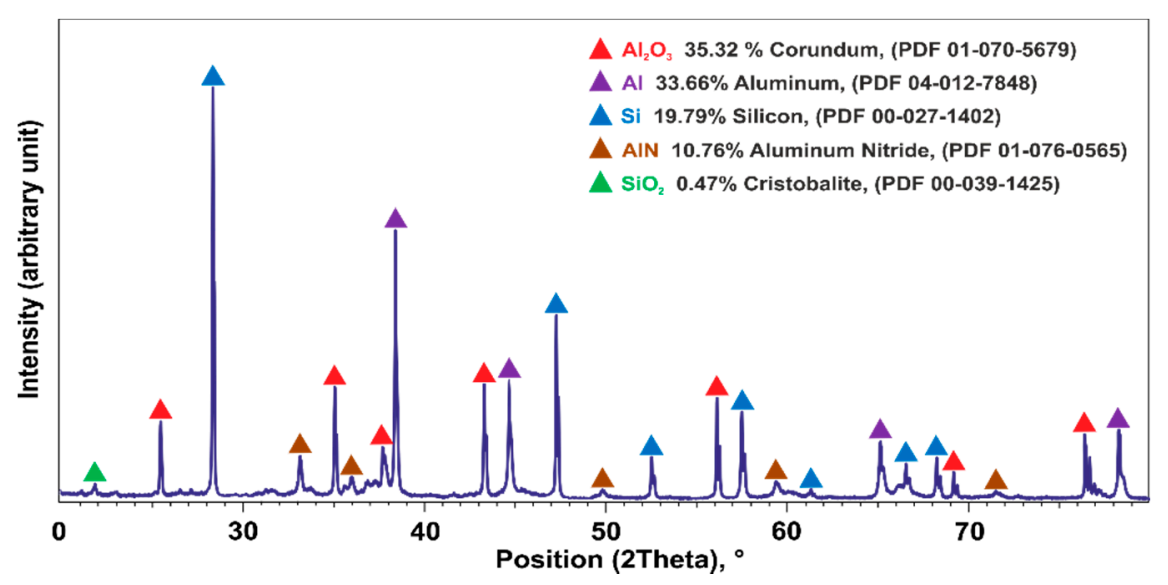

Figure 3. XRD pattern of the fine dross $(<1 \mathrm{~mm})$ that contains non-metallic components.

Table 2. Chemical composition of HCFeMn slag by XRF (wt.\%).

\begin{tabular}{|c|c|c|c|c|c|c|c|c|c|c|c|c|c|}
\hline Sample & $\mathrm{MnO}$ & $\mathrm{SiO}_{2}$ & $\mathrm{CaO}$ & $\mathrm{Al}_{2} \mathrm{O}_{3}$ & $\mathrm{MgO}$ & $\mathrm{Fe}_{2} \mathrm{O}_{3}$ & $\mathrm{~K}_{2} \mathrm{O}$ & $\mathrm{BaO}$ & $\mathrm{SO}_{3}$ & $\mathrm{Na}_{2} \mathrm{O}$ & $\mathrm{TiO}_{2}$ & $\mathrm{SrO}$ & Rest \\
\hline $\begin{array}{c}\text { FeMn } \\
\text { slag }\end{array}$ & 46.18 & 19.24 & 13.52 & 10.94 & 4.11 & 2.29 & 0.96 & 0.94 & 0.75 & 0.39 & 0.33 & 0.29 & 0.07 \\
\hline
\end{tabular}

\subsection{Characteristics of the Products}

The obtained results were studied regarding the characteristics of the reactants in the experiments in the following.

\subsubsection{Interaction of Pure Al with Synthetic Slag}

The metal and slag phases produced via the pure Al interaction with the synthetic slag were easily separated after breaking the crucible. They were characterized by SEM (with EDS analysis), and it was found that small amounts of metal exist in the slag in the form of tiny solidified metal droplets, as illustrated in Figure $4 \mathrm{a}$. This may be due to the short processing time, so that the complete separation of the heavier metal droplets and their settling due to them having a higher density than the slag has not occurred. As these tiny metal particles are insignificant in mass (less than $1 \%$ ) compared to the main separated metal phase in the bottom of the crucible, we can conclude here that the metallic product is easily separable from the slag. A typical SEM image from the metal/slag interfacial area is given in Figure $4 b$, and selected areas were analyzed by EDS. The chemical composition was measured for five different large areas and averages were determined. Obviously, the brighter light grey phase is metallic, with an average of about $79 \mathrm{wt} \% \mathrm{Mn}$ and $21 \mathrm{wt} . \% \mathrm{Al}$.

The small amount of oxygen can be due to the surface oxidation of the metal phase during the sample preparation, and smaller amount may be in the form of dissolved oxygen in the alloy. Regarding the binary $\mathrm{Mn}-\mathrm{Al}$ phase diagram [27] and the concentration of the produced metallic alloy, the metal consisted of a solid solution of $\mathrm{Al}$ in $\mathrm{Mn}, \beta \mathrm{Mn}$, with the highest solubility of $\mathrm{Al}$ in it. The dark grey phase in the SEM image of Figure 4 shows that it is a slag phase that consists of $\mathrm{Ca}, \mathrm{Al}$, and $\mathrm{O}$ elements. The results of local chemical composition analyses by EDS from three different slag areas revealed that it is composed of an average of $35.5 \mathrm{wt} . \% \mathrm{Ca}, 34 \mathrm{wt} . \% \mathrm{O}$, and $29.1 \mathrm{wt}$.\% Al. According to the $\mathrm{CaO}-\mathrm{Al}_{2} \mathrm{O}_{3}$ phase diagram, the slag contains a fine structure of $3 \mathrm{Ca} \cdot \mathrm{Al}_{2} \mathrm{O}_{3}$ and $12 \mathrm{CaO} \cdot 12 \mathrm{Al}_{2} \mathrm{O}_{3}$ phases. 


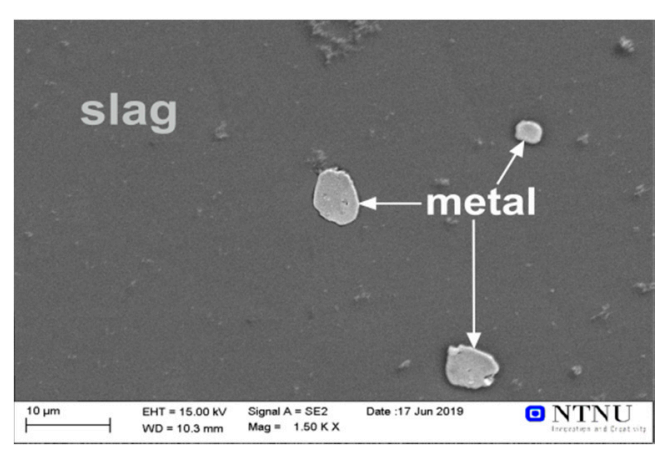

(a)

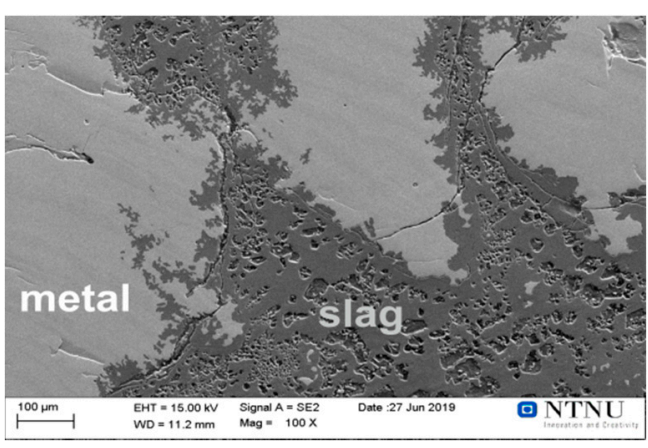

(b)

\begin{tabular}{|c|c|c|c|c|}
\hline \multirow{2}{*}{ Area } & \multicolumn{4}{|c|}{ Chemical composition (wt. \%) } \\
\cline { 2 - 5 } & $\mathrm{Al}$ & $\mathrm{Mn}$ & $\mathrm{Ca}$ & $\mathrm{O}$ \\
\hline avg. from slag & 29.13 & 1.26 & 35.53 & 34.08 \\
\hline avg. from metal & 20.98 & 78.58 & 0.02 & 0.43 \\
\hline
\end{tabular}

(c)

Figure 4. The SEM/EDS microstructural analysis of the cross-section of exp. 1 sample from slag area (a) and metal-slag contact area (b); EDS (c).

The equilibrium in the interacting system at the process temperature was studied by the FactSage thermodynamic software, version 7.3., using the FACT Oxid and FACT Lite databases [28-31]. Figure 5 shows that if we interact a binary $\mathrm{CaO}-\mathrm{MnO}$ mixture with $\mathrm{Al}$, calcium-aluminate slags are produced through the formation of $\mathrm{Al}_{2} \mathrm{O}_{3}$ through the reaction in Equation (1), and its further reaction with the adjacent $\mathrm{CaO}$. Accordingly, metallic $\mathrm{Mn}$ is produced, and if there is excess aluminum for $\mathrm{Mn}$ oxide reduction it yields a $\mathrm{Mn}-\mathrm{Al}$ alloy.

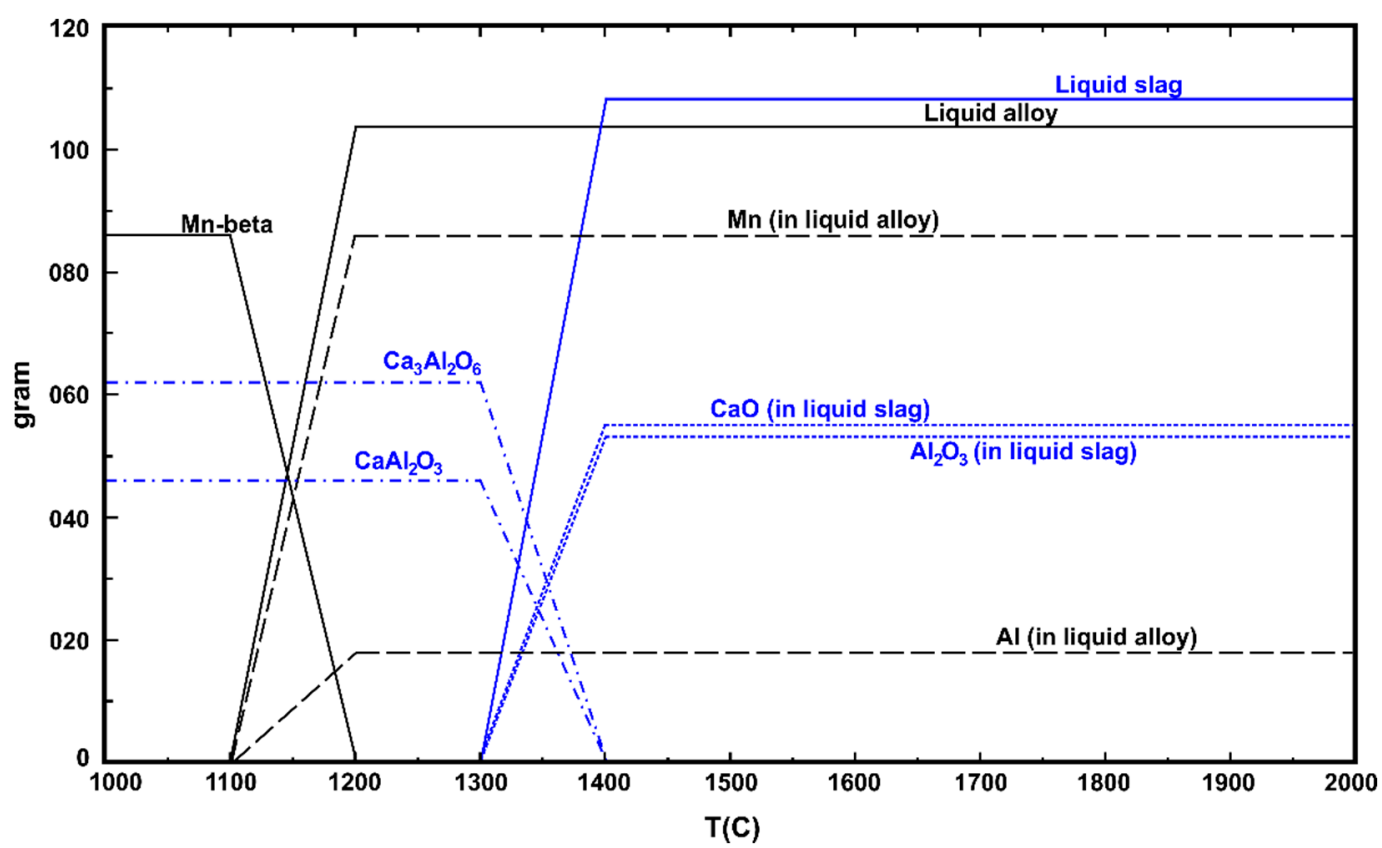

Figure 5. Calculated equilibrium conditions for the interaction of $46 \mathrm{~g}$ Al with a $55 \mathrm{~g} \mathrm{CaO}-111 \mathrm{~g} \mathrm{MnO}$ slag (FactSage ver. 7.3.).

The microstructural characterization evaluation is in good agreement with the equilibrium calculations by FactSage (Figure 5) that show the formation of calcium-aluminate slag with an $\mathrm{Mn}-\mathrm{Al}$ alloy. The same experimental result as the theoretical equilibrium calculations indicates that the applied aluminothermic process is quite fast and has reached almost equilibrium within very short reaction times. 


\subsubsection{Interaction of Al Dross with Synthetic Slag}

Figure $6 \mathrm{~b}$ shows the SEM examination results for the produced metal phase through the interaction of the synthetic slag and $\mathrm{Al}$ dross 1 in exp. 2. The results of the metal chemical composition analyses show that it consisted of $\beta \mathrm{Mn}$ (solid solution of $\mathrm{Al}$ in $\mathrm{Mn}$ ) with an average of about $84 \mathrm{wt} . \% \mathrm{Mn}$ and $12 \mathrm{wt} . \%$ Al. The chemical composition was measured over five different large areas, and averages were then calculated.

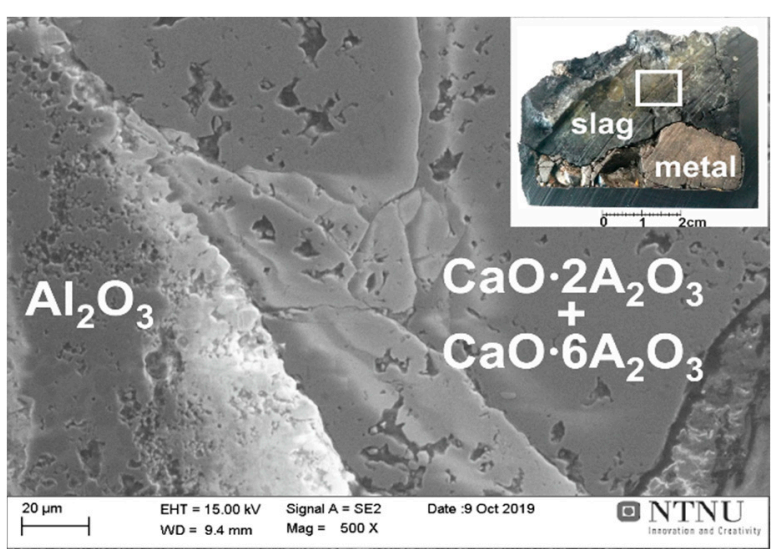

(a)

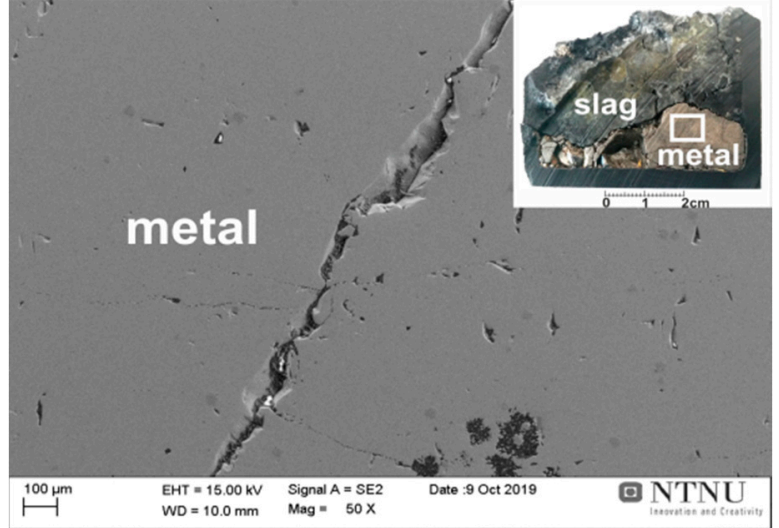

(b)

\begin{tabular}{|c|c|c|c|c|c|}
\hline \multirow{2}{*}{ Area } & \multicolumn{5}{|c|}{ Chemical composition (wt. \%) } \\
\cline { 2 - 6 } & $\mathrm{Al}$ & $\mathrm{Mn}$ & $\mathrm{Ca}$ & $\mathrm{O}$ & $\mathrm{C}$ \\
\hline avg. from slag & 30.02 & 0.02 & 13.16 & 49.58 & 7.22 \\
\hline avg. from metal & 12.01 & 84.19 & 0.02 & 0.44 & 3.34 \\
\hline
\end{tabular}

(c)

Figure 6. The SEM/EDS microstructural analysis of the cross-section of exp. 2 sample from slag area (a) and metal area (b); $\operatorname{EDS}(\mathbf{c})$.

The obtained metal in exp. 2 is richer in Mn compared to exp. 1, and this is due to the lower amount of metallic reactant in the utilized dross 1 than in our estimated metallic $\mathrm{Al}$ above, yielding less $\mathrm{Al}$ in the produced Mn metal. It is worth mentioning that investigating the slag phase indicated that there was no unreacted metallic Al left, showing the formation of completely molten phases at elevated temperatures, complete chemical reactions (1), and proper phase separation. The SEM study of the slag in exp. 2 indicated again a calcium-aluminate slag that contained significant amounts of $\mathrm{CaO} \cdot 2 \mathrm{Al}_{2} \mathrm{O}_{3}$ and $\mathrm{CaO} \cdot 6 \mathrm{Al}_{2} \mathrm{O}_{3}$ phases and a small amount of $\mathrm{Al}_{2} \mathrm{O}_{3}$ phases, which is expected regarding the binary $\mathrm{CaO}-\mathrm{Al}_{2} \mathrm{O}_{3}$ slag system, and it having a higher amount of $\mathrm{Al}_{2} \mathrm{O}_{3}$ in the system compared with exp. 1. Similar to exp. 1, in exp. 2 Mn-free calcium aluminate slag was produced again, indicating the complete conversion of $\mathrm{MnO}$ to metallic $\mathrm{Mn}$. It is worth mentioning that we did not observe the dissolution/degradation of the alumina crucible, as the molten slag is enriched rapidly by $\mathrm{Al}_{2} \mathrm{O}_{3}$ and the retention time is short.

\subsubsection{Interaction of Al-Dross with FeMn Slag}

The results for the interaction of Al dross with HCFeMn slag indicated that in both exps. 3 and 4 we obtain two separable metal and slag phases, as seen in Figure 7. However, it was found that for the exp. 4 with a higher amount of added $\mathrm{CaO}$, we obtain a single large metal, while for the exp. 3 we have some metal balls in the slag with different sizes. This may indicate that the viscosity of the produced slag in exp. 4 is lower than that of exp. 3 , and so the metal droplets join more easily. 


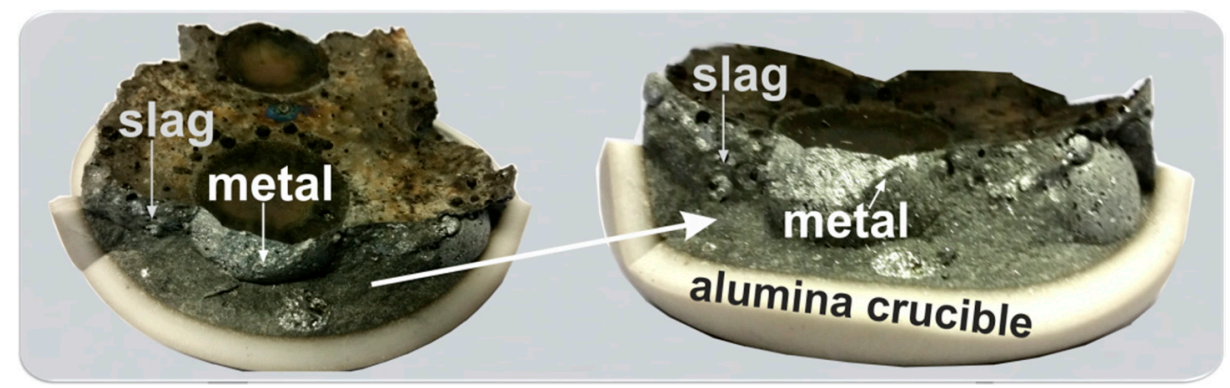

(a)

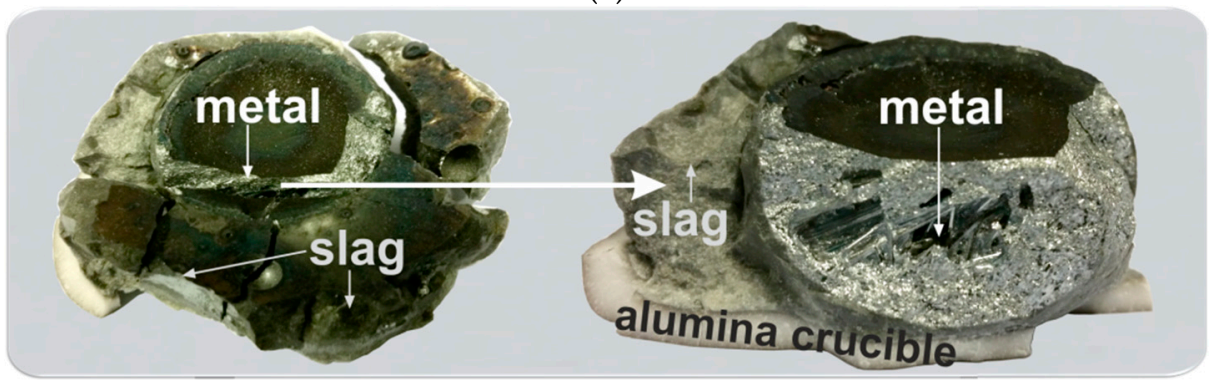

(b)

Figure 7. The broken crucibles after experiments 3 (a) and 4 (b).

The microstructural analyses of the produced metals in exp. 3 and exp. 4 show that they have very close chemical compositions and that both metal products are ternary Al-Mn-Si alloys with small amounts of $\mathrm{Fe}, \mathrm{Mg}$, and $\mathrm{Ca}$, as illustrated in Figure 8 and Table 3. The existence of Fe in the alloys is obviously due to the aluminothermic reduction of iron oxide from the FeMn slag, as its reduction is possible via chemical reaction (2) as we do not have $\mathrm{Fe}$ in the $\mathrm{Al}$ dross. Moreover, the chemical analysis of the produced slags indicated that there are calcium aluminate slags (about 99\%) with minor amounts of $\mathrm{SiO}_{2}$ and $\mathrm{MgO}$. This indicates that almost all the $\mathrm{SiO}_{2}$ in the FeMn slag (about 20\% in Table 1) has been reduced via the chemical reaction (3), and therefore the high amount of $\mathrm{Si}$ in the produced alloys is from both the dross 2 (Figure 2) and also the aluminothermic reduction reaction.

$$
\begin{aligned}
2 \mathrm{Al}+\mathrm{Fe}_{2} \mathrm{O}_{3} & =2 \mathrm{Fe}+\mathrm{Al}_{2} \mathrm{O}_{3} \Delta \mathrm{H}\left(1500{ }^{\circ} \mathrm{C}\right)=-877.1 \mathrm{~kJ} / \mathrm{mol}, \\
2 \mathrm{Al}+1.5 \mathrm{SiO}_{2} & =1.5 \mathrm{Si}+\mathrm{Al}_{2} \mathrm{O}_{3} \Delta \mathrm{H}\left(1500{ }^{\circ} \mathrm{C}\right)=-262.5 \mathrm{~kJ} / \mathrm{mol} .
\end{aligned}
$$

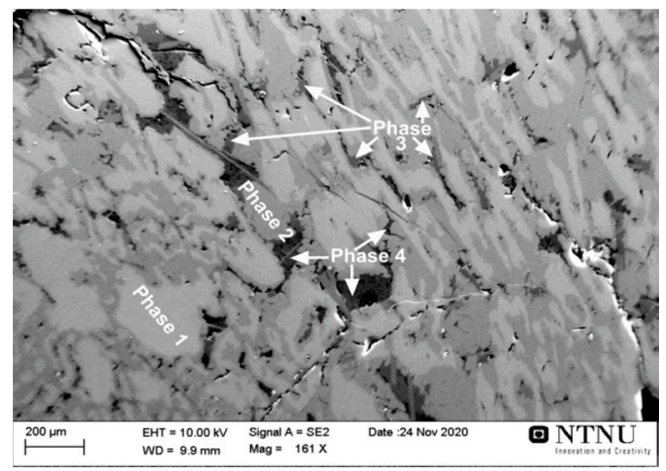

(a)

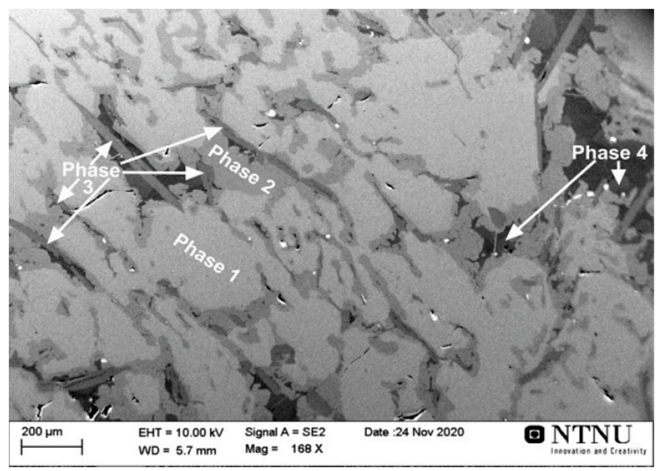

(b)

Figure 8. The SEM/EDS microstructural analysis of the cross-section of the metal produced in exp. 3 (a) and exp. 4 (b). 
Table 3. Measured compositions for metals in exp. 3 and exp. 4 (wt.\%).

\begin{tabular}{ccccccccc}
\hline & Al & Mn & Si & Mg & Fe & Ca & C & O \\
\hline Metal 3 overall composition & 41.33 & 31.12 & 21.80 & 0.59 & 2.54 & 0.62 & 1.60 & 0.41 \\
Metal 4 overall composition & 39.63 & 31.74 & 21.62 & 0.41 & 3.09 & 1.61 & 1.80 & 0.11 \\
Phase 1 & 39.35 & 42.25 & 13.81 & 0.45 & 3.44 & 0.02 & 0.69 & 0.00 \\
Phase 2 & 30.05 & 26.72 & 38.55 & 0.38 & 3.39 & 0.02 & 0.90 & 0.00 \\
Phase 3 & 32.01 & 0.44 & 39.70 & 0.36 & 0.20 & 25.95 & 1.06 & 0.30 \\
Phase 4 & 0.84 & 0.17 & 97.18 & 0.12 & 0.03 & 0.00 & 1.53 & 0.13 \\
\hline
\end{tabular}

The small amounts of $\mathrm{Ca}$ and $\mathrm{Mg}$ in the produced metals are due to the distribution of these elements between the slag and metal. There is considerable $\mathrm{CaO}$ and, in lower levels, $\mathrm{MgO}$ in the reactive system, and these oxides can be partially reduced by $\mathrm{Al}$ due to their low chemical activities in the liquid metal, while their oxides have much higher chemical activities in the slags. Therefore, the mass transport of $\mathrm{Ca}$ and $\mathrm{Mg}$ occurs in the system via chemical reactions (4) and (5).

$$
\begin{gathered}
2 \mathrm{Al}+3 \mathrm{CaO}=3 \mathrm{Ca}+\mathrm{Al}_{2} \mathrm{O}_{3} \Delta \mathrm{H}\left(1500{ }^{\circ} \mathrm{C}\right)=250 \mathrm{~kJ} / \mathrm{mol}, \\
2 \mathrm{Al}+3 \mathrm{MgO}=3 \mathrm{Mg}+\mathrm{Al}_{2} \mathrm{O}_{3} \Delta \mathrm{H}\left(1500{ }^{\circ} \mathrm{C}\right)=142.5 \mathrm{~kJ} / \mathrm{mol} .
\end{gathered}
$$

Comparing the compositions of $\mathrm{Ca}$ and $\mathrm{Mg}$ in the produced slags 3 and 4 indicates that more $\mathrm{Ca}$ has been transferred into the metal phase with increasing $\mathrm{CaO}$ in the charge. Meanwhile, the Mg in the metal phase has been decreased. This can be evaluated with regard to the slag thermochemistry and the effect of the $\mathrm{CaO}$ addition on the slag. When adding more $\mathrm{CaO}$, as in exp. 4, this causes the increased chemical activity of the $\mathrm{CaO}$ in the slag and enhances the kinetics of reaction (4), yielding a metallic product with a higher $\mathrm{Ca}$ content. On the other hand, more $\mathrm{CaO}$ in the slag reduces the chemical activity of $\mathrm{MgO}$ due to the decreasing $\mathrm{MgO}$ concentration, which consequently decreases the $\mathrm{MgO}$ chemical activity. Hence, the extent of chemical reaction (5) is reduced and less $\mathrm{Mg}$ is transferred into the metal phase.

Figure 8 shows the microstructures of the produced metals in exp. 3 and 4 . As can be seen, both metals have relatively similar phases with regard to the contrast; however, the amounts of the phases are different. The overall chemical composition of the phases measured for $4-5$ very large areas $(2 \mathrm{~mm} \times 2 \mathrm{~mm})$ and then averaged is given in Table 3 . It is observed that the produced metals in the two experiments have very close chemical compositions of about $40-41 \% \mathrm{Mn}, 31 \% \mathrm{Al}, 21 \% \mathrm{Si}$, and $2.5-3.1 \% \mathrm{Fe}$. Excluding the C (from sample coating) and the minor oxygen concentration that may be due to sample surface oxidation, metal 4 has a two-times higher $\mathrm{Ca}$ concentration. The higher $\mathrm{Ca}$ concentration in the alloy 4 is attributed to the use of more $\mathrm{CaO}$ in the charge mixture in comparison with exp. 3, and this causes greater $\mathrm{CaO}$ chemical activity and the faster proceeding of the chemical reaction (4) in exp. 4.

The provided information in Table 3 shows that the microstructures of the produced Mn-Al-Si alloys in the two experiments 3 and 4 have similarities with regard to the type of coexisting phases, while their distribution is slightly different. In particular, phase 3 , which is rich in $\mathrm{Ca}$, is in a higher amount in metal 4 with a needle shape, while it is in a smaller size and irregular shape in metal 3. The dominant phase 1 in metal 4 has a larger size and most likely a higher amount than that in metal 3 . However, the significantly higher amount of phase 2 in metal 3 than that in metal 4 provides relatively overall close chemical compositions for the two alloys, as the two phases 1 and 2 are the dominant phases.

The SEM/EDS analysis of the produced slags 3 and 4 indicated that they are calcium aluminate slags with minor impurities. It was found that slag 3 consists of two main phases of $\mathrm{CaO} \cdot \mathrm{Al}_{2} \mathrm{O}_{3}$ and $\mathrm{CaO} \cdot 2 \mathrm{Al}_{2} \mathrm{O}_{3}$, with an overall chemical composition of $24 \mathrm{wt} . \% \mathrm{CaO}-$ 76 wt. $\% \mathrm{Al}_{2} \mathrm{O}_{3}$. The slag 4 was found to consist of $\mathrm{CaO} \cdot \mathrm{Al}_{2} \mathrm{O}_{3}$ and $12 \mathrm{CaO} \cdot 7 \mathrm{Al}_{2} \mathrm{O}_{3}$ phases. Obviously, the addition of more lime has affected the characteristics of the produced slags 
and the form of the calcium-aluminate phases, as expected with regard to the $\mathrm{CaO} \cdot \mathrm{Al}_{2} \mathrm{O}_{3}$ binary phase diagram.

As was previously mentioned, the produced metal has a low concentration of $C$, as shown in in Table 3 for the metal phase, which is due to sample coating. It is worth mentioning that in the Al-rich particles (separated from $\mathrm{Al}$ dross) and the utilized ferromanganese slag, we had insignificant amounts of $C$, and hence we did not expect this impurity in the produced metal and slag phases. We also expect the same for $\mathrm{P}$, as again the two reactants are low in $\mathrm{P}$, and in particular $\mathrm{P}$ in the original $\mathrm{Al}$ dross, where it was more distributed due to the fine milling. The concentration of $\mathrm{O}$ impurity is low, as shown in Figure $6 \mathrm{~b}$ and Table 3, and we believe that $\mathrm{O}$ may be more concentrated on the metal sample surface due to surface oxidation. The sulfur content of the metal was insignificant and it was not detected by EDS analysis; hence, the $\mathrm{S}$ from ferromanganese slag may be more distributed in the produced slag phase, and probably some of it was lost due to evaporation.

\section{Process Evaluation}

The present experimental work indicates that it is possible to use a portion of the added metallic $\mathrm{Al}$ (pure or in dross) to conduct the aluminothermic reduction, and the rest of the $\mathrm{Al}$ is distributed in the metallic product. Hence, $\mathrm{Al}$ recovery depends on the $\mathrm{MnO}$ and $\mathrm{SiO}_{2}$ in the ferromanganese slag and also the amount of it. Meanwhile, it was indicated that there was a complete recovery of $\mathrm{Mn}$ and $\mathrm{Si}$ from the ferromanganese slag. Considering the results of this work and introducing a method for the aluminum dross and ferromanganese slag valorization, the process is shortly evaluated as follows.

\subsection{Process Flexibility}

The change of reactant materials from pure (metallic $\mathrm{Al}$, $\mathrm{MnO}$ powder) to real industrial (Al dross, $\mathrm{HCFeMn}$ ) materials indicates that it is possible to have a complete aluminothermic reduction process in both cases. Moreover, as a result of the reaction a complete manganese oxide reduction to metallic manganese was achieved in both cases, as illustrated in Figure 9. The present study shows that the process yields both $\mathrm{Mn}-\mathrm{Al}$ and Mn-Al-Si alloys as the main product. The metallic product can be used in both the $\mathrm{Al}$ and steel industry - for instance, to produce Transformation Induced Plasticity (TRIP) and Twinning Induced Plasticity (TWIP) steels [32]. The produced calcium-aluminate slags that contain significant amounts of $\mathrm{Al}_{2} \mathrm{O}_{3}$ and $\mathrm{CaO}$ can be used easily in different industries, such as the cement, steelmaking, and aluminum industry, to recover alumina [33]. In the present study, pure $\mathrm{Al}$ and pure $\mathrm{MnO}-\mathrm{CaO}$ slag were examined, yielding a high-purity $\mathrm{Mn}-\mathrm{Al}$ alloy and a clean $\mathrm{CaO}-\mathrm{Al}_{2} \mathrm{O}_{3}$ slag. Moreover, an upgraded $\mathrm{Al}$ dross, high in $\mathrm{Al}$, was utilized to reduce industrial ferromanganese slag, and Mn-Al-Si alloys were obtained.

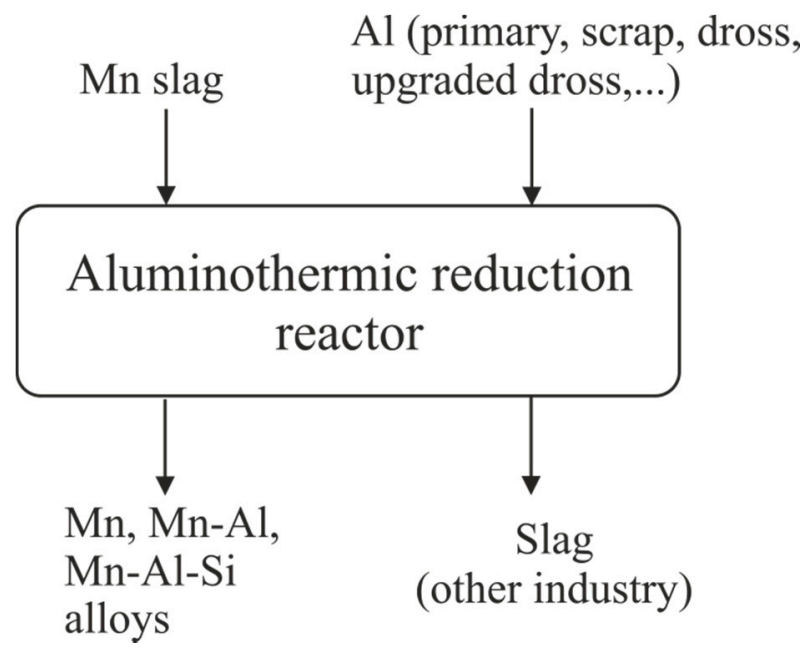

Figure 9. A simplified flowsheet of the process showing its flexibility. 
The applied process in this research is very flexible for recycling Al scrap, Al dross, etc., and producing valuable $\mathrm{Mn}$ and $\mathrm{Mn}-\mathrm{Al}$ alloys. Obviously, the thermochemistry of the slag and metal system at elevated temperatures is very important, affecting the quality of the process products. In order to fully separate the reduced metal from the remaining slag, it is emphasized that the observed lab results are validated at a large scale. like the current ferromanganese process in which molten metal and slag are well separated due to their large density differences. A molten metal with $41 \% \mathrm{Al}-32 \% \mathrm{Mn}-22 \% \mathrm{Si}-3 \% \mathrm{Fe}$ and $2 \% \mathrm{Ca}$ (as metals in trials 3 and 4 in Table 3 ) has an average density of $3.9 \mathrm{~kg} / \mathrm{cm}^{3}$ (considering insignificant volume changes due to mixing), which is larger than the measured densities of calcium aluminate slags, that are in the range of $2.5-2.8 \mathrm{~kg} / \mathrm{cm}^{3}$ at $1600{ }^{\circ} \mathrm{C}$ [34]. The lighter slag phase is obviously floating over the metal phase and can be separated easily in practice from the metal.

\subsection{Energy Consumption}

The process energy consumption for the presented aluminothermic reduction is mainly for heating the reactant materials to the high temperatures for the chemical reaction (1) to proceed. When the reaction is started, it is self-propagating and will continue until process completion. Hence, depending on the added reactants, the composition of the produced metal varies, as outlined above. The process energy consumption is, hence, very dependent on the characteristics of the reactants and their amounts. As the $\mathrm{Al}$ dross is a complex material that contains metallic $\mathrm{Al}$ and non-metallic components such as $\mathrm{Al}_{2} \mathrm{O}_{3}, \mathrm{Al}_{4} \mathrm{C}_{3}, \mathrm{AlN}$, etc., it is difficult to provide highly representative numbers. Hence, the energy consumption was calculated for the case where $\mathrm{Al}$ interacted with $\mathrm{MnO}-\mathrm{CaO}$ slag to produce $\mathrm{Mn}$ and $\mathrm{Mn}-\mathrm{Al}$ alloys, according to the results in Section 3.2.1. Figure 10 indicates the calculated energy consumptions to produce unit mass of the metal for the case where the chemical composition of the produced slag is fixed (unity molar ratio of $\mathrm{CaO} / \mathrm{Al}_{2} \mathrm{O}_{3}$ at $1773 \mathrm{~K}$ ) and the amount of $\mathrm{Al}$ in the alloy varies. The calculations were completed using HSC Chemistry software version 7 for two cases-i.e., case 1, where all reactants are heated to the process temperature, and the heat generated by the reaction causes the temperature to rise in the reactor. For case 2, the enthalpy of the exothermic reaction (1) is completely utilized to heat up the charge as well. In case 2, it can be assumed that small amounts of the reactants are initially interact and then the rest of the charge is added so that the heat generated by the reactions is mostly utilized to heat up the more added cold charge to the reaction temperature. The latter case 2 is of course technology-dependent, and can be implemented in different ways in practice, which is beyond this study.

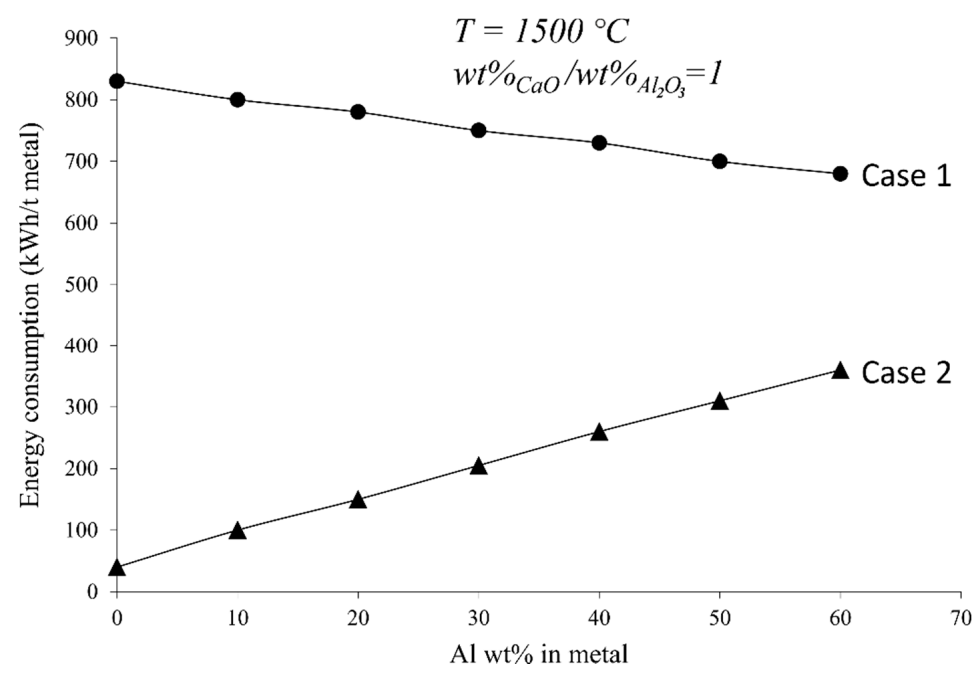

Figure 10. Calculated energy consumption for the Mn-Al alloy production from $\mathrm{MnO}-\mathrm{CaO}$ slags. Case1: reactants are heated. Case 2: enthalpy of reactions is used to heat the reactants. 
According to Figure 10, the aluminothermic process for Mn production presented in this work has a very low energy consumption, or, in another word, insignificant energy consumption. This low energy consumption is quite low if we compare it with the energy consumption for making alloys from pure metals, where 2000-3000 kWh/t [35] and $14,000-16,000 \mathrm{kWh} / \mathrm{t}$ [36] electric energy is used for $\mathrm{Mn}$ and $\mathrm{Al}$ production, respectively. Obviously, the energy consumption depends on the target alloy composition, and if the heat generated by the reaction (1) is not consumed to heat the materials, the energy consumption is slightly decreased with an increasing $\mathrm{Al}$ content. However, if the required heat for warming up the reactants is from the heat of reaction (1), the energy consumption is lower; however, it increases slightly with the increasing $\mathrm{Al}$ content of the target alloy. It is worth mentioning that the process energy consumption is lower in both cases, but the applied procedure in practice is more technology-dependent.

\section{Conclusions}

The aluminothermic reduction of MnO-containing slags was studied through using pure $\mathrm{Al}$ and two types of white $\mathrm{Al}$ dross, and the following results were obtained.

1. Pure $\mathrm{Mn}-\mathrm{Al}$ alloys were obtained via the aluminothermic reduction of highly pure synthetic $\mathrm{CaO}-\mathrm{MnO}$ slag by pure $\mathrm{Al}$, and with $\mathrm{Al}$ dross from the primary $\mathrm{Al}$ production process.

2. The composition of the Mn-Al metal and the corresponding slag depends on the charge compositions and amounts.

3. Mn-Al-Si alloys were produced using upgraded industrial $\mathrm{Al}$ dross and industrial ferromanganese slag, and the metal composition is slightly dependent on additional flux (lime) addition. More $\mathrm{Ca}$ is transferred to the metal when the $\mathrm{CaO}$ content of slag is increased.

4. The composition and microstructure of the produced slag are very dependent on the charge mixture and can be easily engineered.

5. The outlined process is very flexible, and a variety of charge mixtures can be used.

6. The energy consumption of the process is low and is slightly affected by the target metal composition and the applied technology in practice regarding the energy savings.

Author Contributions: Conceptualization, J.S. and A.K.; methodology, J.S. and A.K.; software, J.S.; validation, J.S., A.K., I.J. and S.A.; formal analysis, J.S. and A.K.; investigation, A.K. and J.S.; resources, J.S., A.K., I.J. and S.A.; data curation, J.S. and A.K.; writing—original draft preparation, J.S. and A.K.; writing - review and editing, J.S., A.K., I.J. and S.A.; visualization, A.K. and J.S.; supervision, J.S.; project administration, J.S. and A.K.; funding acquisition, J.S. All authors have read and agreed to the published version of the manuscript.

Funding: This research was funded by SFI Metal Production (Centre for Research-based Innovation), grant number 237738. The APC was funded by SFI Metal Production.

Institutional Review Board Statement: Not applicable.

Informed Consent Statement: Not applicable.

Data Availability Statement: Data available in a publicly accessible repository that does not issue DOIs. Publicly available datasets were analyzed in this study. This data can be found here: https://www.ntnu.edu/metpro.

Acknowledgments: This publication has been funded by the SFI Metal Production (Centre for Research-based Innovation, 237738). The authors gratefully acknowledge the financial support from the Research Council of Norway and the partners of the SFI Metal Production. Special acknowledge to ERAMET and HYDRO company for material supply.

Conflicts of Interest: The funders had no role in the design of the study; in the collection, analysis, or interpretation of data; in the writing of the manuscript; or in the decision to publish the results. On behalf of all the authors, the corresponding author states that there is no conflict of interest. 


\section{References}

1. Torres, J.; Flores Valdés, A.; Almanza Robles, J.M. Elaboration of Al-Mn Alloys by Aluminothermic Reduction of $\mathrm{Mn}_{2} \mathrm{O}_{3}$. Mater. Today 2015, 2, 4963-4970. [CrossRef]

2. Tabereaux, A.T.; Peterson, R.D. Chapter 2.5-Aluminum Production. In Treatise on Process Metallurgy; Seetharaman, S., Ed.; Royal Institute of Technology: Stockholm, Sweden, 2014; Volume 3, pp. 839-917.

3. Mandin, P.; Wüthrich, R.; Roustan, H. Industrial Aluminium Production: The Hall-Heroult Process Modelling. ECS Trans. 2009, 19, 1-10. [CrossRef]

4. Tsakiridis, P.E. Aluminum salt slag characterization and utilization-A review. J. Hazard. Mater. 2012, 2017-2018, 1-10. [CrossRef] [PubMed]

5. International Aluminum Institute. Available online: https://www.world-aluminium.org/statistics/ (accessed on 11 December 2020).

6. Jafari, N.H.; Stark, T.D.; Roper, R. Classification and reactivity of secondary aluminum production waste. J. Hazard. Toxic Radioact. Waste 2014, 18, 04014018. [CrossRef]

7. Adeosun, S.O.; Sekunowo, O.I.; Taiwo, O.O.; Ayoola, W.A.; Machado, A. Physical and Mechanical Properties of aluminum dross. Adv. Mater. 2014, 3, 6-10. [CrossRef]

8. Manfredi, O.; Wuth, W.; Bohlinger, I. Characterizing the physical and chemical properties of aluminum dross. JOM 1997, 49, 48-51. [CrossRef]

9. Masson, D.B.; Taghiei, M.M. Interfacial reactions between aluminum alloys and salt flux during melting. Mater. Trans. 1989, 30, 411-422. [CrossRef]

10. Maung, K.N.; Yoshida, T.; Liu, G.; Lwin, C.M.; Muller, D.B.; Hashimoto, S. Assessment of secondary aluminum reserves of nations. Resour. Conserv. Recycl. 2017, 126, 34-41. [CrossRef]

11. Shinzato, M.C.; Hypolito, R. Effect of disposal of aluminum recycling waste in soil and water bodies. Environ. Earth Sci. 2016, 75, 628-638. [CrossRef]

12. Mankhand, T.R. Recovery of valuable materials from aluminum dross. J. Sustain. Planet. 2012, 3, 86-94.

13. Tsakiridis, P.E.; Oustadakis, P.; Agatzini-Leonardou, S. Aluminium recovery during black dross hydrothermal treatment. J. Environ. Chem. Eng. 2013, 1, 23-32. [CrossRef]

14. Olsen, S.E.; Merete, T.; Lindstad, T. Production of Manganese Ferroalloys; Tapir Akademisk Forlag: Trondheim, Norway, 2007.

15. International Manganese Institute, IMNI Statistics Report 2020. Available online: https:/ /www.manganese.org/ (accessed on 11 December 2020).

16. Safarian, J. Kinetics and Mechanisms of Reduction of MnO-Containing Silicate Slags by Selected Forms of Carbonaceous Materials. PhD Thesis, Norwegian University of Science and Technology (NTNU), Trondheim, Norway, 2007; p. 250.

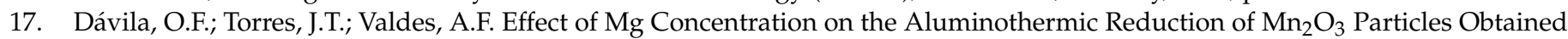
from Cathodes of Discharged Alkaline Batteries: Mathematical Modeling and Experimental Results. Metals 2019, 9, 49. [CrossRef]

18. Kavitha, R.; McDermid, J.R. On the in-situ aluminothermic reduction of manganese oxides in continuous galvanizing baths. Surf. Coat. Technol. 2012, 212, 152-158. [CrossRef]

19. Cruz-Crespo, A.; Puchol, R.Q.; González, L.P.; Gómez Pérez, C.R.; Cedré, E.D.; Jacomino, J.G. Effect of CaO from the slag system $\mathrm{MnO}-\mathrm{SiO}_{2}-\mathrm{CaO}$ on the chemical composition of weld metal. Weld. Int. 2010, 24, 518-523. [CrossRef]

20. Monteiro, M.R.; Swinbourne, D.R.; Rankin, W.J. Metallothermic reduction of manganese-bearing slags. AusIMM Proc. 1998, 303, $1-5$.

21. Taşyürek, K.C.; Buğdayc1, M.; Yücel, O. Reduction Conditions of Metallic Calcium from Magnesium Production Residues. Metals 2018, 8, 383. [CrossRef]

22. Jiaxing, S.; Tao, G.; Wen, D.; Yiming, M.; Xiang, F.; Hao, W. Study on Thermal Chemical Reaction of $\mathrm{Al} / \mathrm{MnO}_{2} \mathrm{Thermite}_{\mathrm{IOP}}$ Conf. Ser. Earth Environ. Sci. 2018, 186, 1-6. [CrossRef]

23. Sarangi, B.; Sarangi, A.; Ray, H.S. Kinetics of aluminothermic reduction of $\mathrm{MnO}_{2}$ and $\mathrm{Fe}_{2} \mathrm{O}_{3}$ : A thermoanalytical investigation. ISIJ Int. 1996, 36, 1135-1141. [CrossRef]

24. Bhoi, B.; Murthy, B.V.R.; Datta, P.; Rajeev; Jouhari, A.K. Studies on Aluminothermic Reduction of Manganese ore for FerroManganese Making. In Proceeding: Ferro Alloy Industries in the Liberalised Economy; Vatsh, A.K., Singh, S.D., Gas, N.G., Ramachandrarao, P., Eds.; NML: Jainshedpur, India, 1997; pp. 66-70.

25. Eveno, M.; Duran, A.; Castaing, J. A portable X-ray diffraction apparatus for in situ analyses of masters' paintings. Appl. Phys. A 2010, 100, 577-584. [CrossRef]

26. Azof, F.I.; Jinglin You, K.T.; Safarian, J. Synthesis and Characterization of $12 \mathrm{CaO} \cdot 7 \mathrm{Al}_{2} \mathrm{O}_{3}$ Slags: The Effects of Impurities and Atmospheres on the Phase Relations. Metall. Mater. Trans. B 2020, 51, 2689-2710. [CrossRef]

27. Liu, X.J.; Ohnuma, I.; Kainuma, R.; Ishida, K. Thermodynamic assessment of the Aluminum-Manganese (Al-Mn) binary phase diagram. JPE 1999, 20, 45-56. [CrossRef]

28. Bale, C.W.; Chartrand, P.; Decterov, S.A.; Eriksson, G.; Hack, K.; Mahfoud, R.B.; Melançon, J.; Pelton, A.D.; Petersen, S. FactSage thermochemical software and databases. Calphad 2002, 26, 189-228. [CrossRef]

29. Bale, C.W.; Bélisle, E.; Chartrand, P.; Decterov, S.A.; Eriksson, G.; Hack, K.; Jung, I.H.; Kang, Y.B.; Melançon, J.; Pelton, A.D.; et al. FactSage thermochemical software and databases-Recent developments. Calphad 2009, 33, 295-311. [CrossRef] 
30. Bale, C.W.; Bélisle, E.; Chartrand, P.; Decterov, S.A.; Eriksson, G.; Gheribi, A.E.; Hack, K.; Jung, I.H.; Kang, Y.B.; Melançon, J.; et al. FactSage thermochemical software and databases, 2010-2016. Calphad 2016, 54, 35-53. [CrossRef]

31. Jung, I.H.; Van Ende, M.A. Computational Thermodynamic Calculations: FactSage from CALPHAD Thermodynamic Database to Virtual Process Simulation. Metall. Mater. Trans. B 2020, 51, 1851-1874. [CrossRef]

32. Safarian, J.; Kolbeinsen, L. Purity requirements for Mn-alloys for producing high manganese TRIP and TWIP steels. In Proceedings of the INFACON XIII: The Thirteenth International Ferroalloys Congress, Almaty, Kazakhstan, 9-12 June 2013; Volume II, pp. 175-183.

33. Azof, F.I.; Safarian, J. Leaching kinetics and mechanism of slag produced from smelting-reduction of bauxite for alumina recovery. Hydrometallurgy 2020, 195, 1-13. [CrossRef]

34. Keene, B.J.; Mills, K.C. Chapter 8-Densities of molten slags. In Slag Atlas, 2nd ed.; Stahleisen, V., Eisenhüttenleute, V.D., Eds.; Verlag Stahleisen GmbH: Dusseldorf, Germany, 1995; pp. 313-348.

35. Ahmed, A.; Halfa, H.; El-Fawakhry, M.K.; El-Faramawy, H.; Eissa, M. Parameters Affecting Energy Consumption for Producing High Carbon Ferromanganese in a Closed Submerged Arc Furnace. J. Iron Steel Res. Int. 2014, 21, 666-672. [CrossRef]

36. IEA. Aluminium. 2020. Available online: https://www.iea.org/reports/aluminium (accessed on 11 December 2020). 